\title{
Body Weight Baseline Flag
}

National Cancer Institute

\section{Source}

National Cancer Institute. Body Weight Baseline Flag. NCI Thesaurus. Code C119780.

An indication or description that body weight data is a baseline value. 